Jpn. J. Oral Biol., $33: 446-452,1991$.

\title{
口腔での食品形態識別能に関する研究
}

一一第 1 報 : 食品形態の識別に及ぼす

食品テクスチャーの影響——

\author{
堀 尾強 河村 洋二郎* \\ 甲子園大学・栄養学部・生理学研究室 \\ ${ }^{*}$ 大阪大学歯学部名誉教授
}

〔受付: 平成 3 年 4 月 5 日〕

\section{Relations between texture of food and oral stereognostic function}

\author{
Tsuyoshi Horio and Yojiro Kawamura \\ Physiology Laboratory, Faculty of Nutrition. \\ Koshien University 10-1 Momijigaoka, \\ Takarazuka. Hyogo, 665, JAPAN \\ [Accepted for publication: April 5, 1991]
}

Key words : oral stereognosis / food texture

\begin{abstract}
Relationships between texture of food and oral stereognosis were evaluated, and oral stereognosis was also compared with manual and visual sensory functions for discrimination of food materials.

The oral stereognosis test was performed in healthy Japanese university students aged between 19 and 21. Six different forms of the test materials made by food materials and acryl with different texture were used.

In case of manual evaluation, the hardest material such as acryl showed the least errors, while in case of oral evaluation the number of errors was not related to hardness. In the very soft material such as bean curd, the errors with oral evaluation were less than that with manual evaluation.

The smallest material $(10 \mathrm{~mm} \times 4 \mathrm{~mm})$ showed the most errors in case of manual evaluation, while there were no differences in the number of errors between the large material $(30 \mathrm{~mm} \times 12 \mathrm{~mm})$ and the small material $(10 \mathrm{~mm} \times 4 \mathrm{~mm})$ in case of oral evaluation.

These results suggested that oral stereognostic evaluation of soft food and small food was more sensitive than those of the manual evaluation.
\end{abstract}

\section{緒言}

口に入れた食品の硬さや，粘着性などの性状及 びその形や大きさの判定には, 主として舌, 口唇, 煩, 口腔軟組織の感覚, 歯牙感覚および顎筋や䪽 関節よりの求心性情報などが 重要な役割を演じて いる ${ }^{1-9)}$ 。しかし，口腔感覚による食品の形態の弁
別・認知の能力と食品の物理的性質であるテクス チャーとの関係については十分には研究がなされ ておらずなお不明な点が多い。本研究ではいろい ろ物理的性質の異なる食品について，その形態を 弁別する機能が口腔感覚, 視覚, 手の感覚でいか に異なるかを検討した。

干665 宝塚市紅葉ケ丘10-1 


\section{材料と方法}

<実験 $1>$ 口腔感覚, 手の感覚および視覚の食 品形態識別能の比較

被験者には健康な男子大学生10名, 女子大学生 6 名合計 16 名を選んだ。食後 30 分以上経過してい ることを確認し，喫煙者には実験30分前から禁煙 を命じた。被験者の視力は両眼とも 0.8 以上で視 覚による物質の立体像の識別に支障がない人を選 んだ。試料には，テクスチャーの異なるアクリ ル, ニンジン, カマボコ, ハンペン, トウフの 5 種類を用いた。各試料の形状は W einberg ら ${ }^{10)}$ 参考にして，上からみた形が Fig. 1 に示したと おり，それぞれ異なる 6 種類を用いた。試料の厚 さは $0.5 \mathrm{~cm}$ に調整した。試料の硬度, 凝集性, ガ ム性, たわみ, 付着性, 粘着性などの物理的性質 はテクスチュロメーター（全研, GTX-2-IN) を 用いて測定した ${ }^{11,12)}$ 。プランジャーとしてはルサ イト $18 \phi$ 型のものを用い， クリアランスは $2 \mathrm{~mm}$ とした。試料の厚さおよびクリアランスが異なる ので值に堀尾，河村 ${ }^{11,12)}$ の報告とは少し相違があ る。

各試料について測定したテクスチャーを Table 1 に示した。硬度はアクリル19.20, ニンジン13.2, カマボコ 2.28, ハンペン 0.42 , トゥフ0.15の順で 小さくなった。凝集性, ガム性は硬度と同じ順に 值が小さくなった。たわみはニンジン，カマボコ， ハンペンはアクリル，トウフに比ベてやや值が大 きかった。どの試料も付着性, 粘着性はなかった。

ロに入れて試料の形態を識別させる実験では， 目を閉じ大きく口を開けた被験者の舌の上に実験 者が試料をのせた後，口を閉じさせて目を開けさ せ， 口腔内で自由に形態を識別させた上，あら かじめ用意した図の中からどの形であったかを答 えさせた。手によって試料の形態を識別させる実 験では, 被験者の前に試料が見えないように被験 者が手を通す穴のあいた「ついたて」を置き，両 手を「ついたて」に通させ, 手のひらを上に向け させた。実験者は試料を被験者の片方の手の指の 上に置き，被験者には反対側の指を使って形を識 別させ，図の中からどの形であったかを指摘させ た。視覚により試料形態を識別させる実験では,
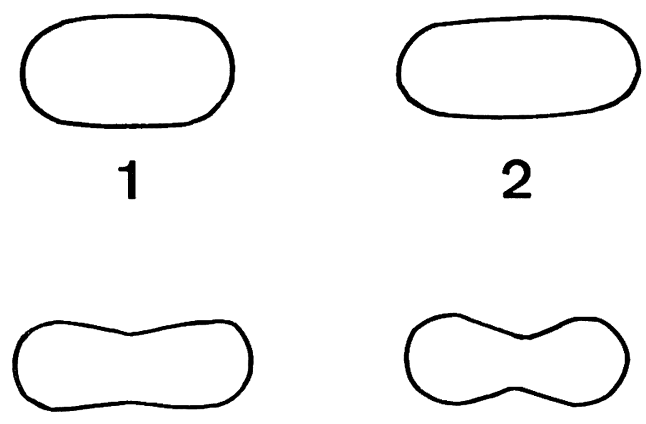

3

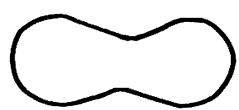

4
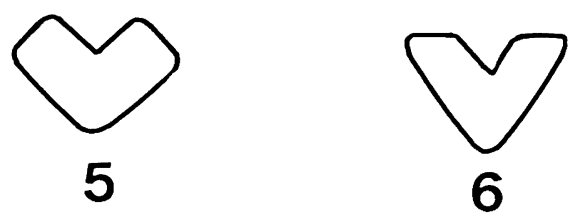

$\overline{1 \mathrm{~cm}}$

Fig. 1 Form of test material (Experiment 1)

目を閉じている被験者の前の黒い皿の中央に試料 を置き，合図とともに目を開かせ試料と同じ形の ものを皿の隣においた図表の中から選ばせた。試 料と目の距離を約 $35 \mathrm{~cm}$ とし，机面と被験者の目 線とで作る角度は約70度であった。試料呈示時間 はShelton ら ${ }^{13)}$ を参考にして10秒間とした。

各試料の形態識別の誤答数の相違の有無は， 2 次元及び 3 元分散分析法, 下位検定は NewmanKeuls 法を用いて統計的に解析した。

<実験 $2>$ 同一形態で大きさが異なる場合の食 品形態識別能

被験者には健康な男子大学生 8 名, 女子大学生 3 名合計11名を選んだ。試料にはニンジン, トウ フを用い，試料の形態は Fig. 2 に示すように 4 種類であった。試料の大きさは平面の長さ比が 1 : $2: 3$, 面積では $1: 4: 9$ の比で厚さはすべて $0.5 \mathrm{~cm}$ に調整した。その他の方法は実験 1 と同様 の手続きで行った。

<実験 $3>$ 円と棈円の食品形態識別能

被験者には健康な男子大学生21名, 女子大学生 5 名合計 26 名を選んだ。試料にはアクリル，ニン 
歯基磷誌 $33: 446-452,1991$.

Table 1 Physical Character of Materials.

\begin{tabular}{llcccccc}
\hline & Hardness & Cohesiveness & Gumminess & Flexibility & Adhesiveness & Stickiness \\
\hline A & Acryl & 19.20 & 1.00 & 1920.00 & 10.5 & 0.00 & 0.00 \\
B & Carrot & 13.20 & 0.91 & 1198.73 & 11.9 & 0.00 & 0.00 \\
C & Boiled Fish-Paste & 2.28 & 0.81 & 180.65 & 11.5 & 0.00 & 0.00 \\
D & Steamed Fish-Paste & 0.42 & 0.77 & 31.98 & 11.3 & 0.00 & 0.00 \\
E & Bean Curd & 0.15 & 0.66 & 9.67 & 10.7 & 0.00 & 0.00 \\
\hline
\end{tabular}

Materials are shown in order of hardness.

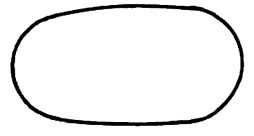

1

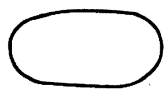

5

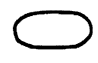

9

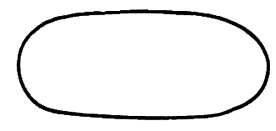

2

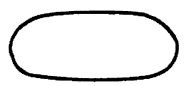

6

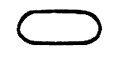

10

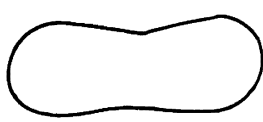

3

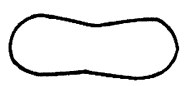

7

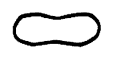

11

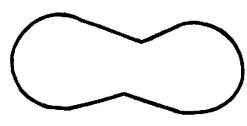

4

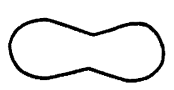

8

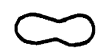

12

Fig. 2 Size of test material (Experiment 2)

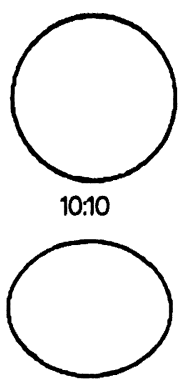

$10: 8.5$

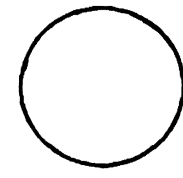

10:9.5

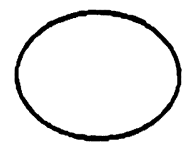

$10: 8.0$

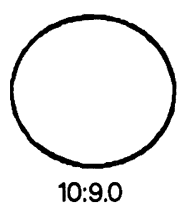

$10 \mathrm{~mm}$

Fig. 3 Form of test material (Experiment 3)

ジン, トウフを用いた。円形の食品の直径は10 $\mathrm{mm}$, 楕円形の長軸の直径は $10 \mathrm{~mm}$ であった。棈 円の長軸と短軸の 比は $10: 9.5,10: 9.0,10$ : 8.5, $10: 8.0$ の 4 種類であった（Fig. 3)。3 件法 を用い，2つの円と 1 つの楕円の 3 つを 1 組とし て, そのうち棈円 1 つだけを選ばせた。楕円の提
示順は明らかに楕円とわかる $10: 8.0$ のものから 段々円に近いものへと提示した。 3 件法では $1 / 3$ の確率で正解の可能性があるので, プロビット法 で処理した後の正解率で比較した。その他の方法 は実験 1 と同様の手続きで行った。

\section{結果}

<実験 $1>$ Fig. 4 は各試料の形態別の誤答数の 平均を示した。口による各試料形態の識別の平均 の誤答数では，アクリル $1.1 \pm 0.2$ (平均值士標準 誤差), ニンジン $1.3 \pm 0.2$, カマボコ $1.3 \pm 0.2$, 八 ンペン $1.5 \pm 0.2, \quad ト ゥ>1.3 \pm 0.2$ となり，ロでは テクスチャーの違いによって誤答数に有意な違い がみられなかった。手による形態の識別の誤答数 では最も少ないアクリルが $0.4 \pm 0.1$ であり，アク リルでの誤答数はニンジンの $1.3 \pm 0.2$, カマボコ の $0.9 \pm 0.3$, ハンペンの $1.7 \pm 0.3$, トゥフ $2.4 \pm$ 
0.2 のいずれよりも有意に少なかった（ $\mathrm{p}<0.05 ）$ 。 また，誤答数の最も多いトウフは他の試料よりも 有意に誤答数が多かった（p<0.01）。手による形 態識別では硬いものほど間違いが 少なくなる傾向 がみられた。視覚による形態の識別では誤りはア

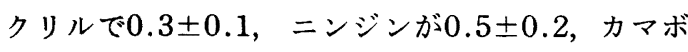
コでは $0.4 \pm 0.2$, ハンペン $0.3 \pm 0.1, \quad$ トウフが $0.5 \pm 0.2$ といずれも手による識別，口による識別 よりも誤答数が少なかった $(\mathrm{p}<0.01)$ 。

どの形と間違えたかを Table 2 に示した。形 1 では口腔, 手あるいは視覚と感覚の種類を問わず 1 を 2 とよく間違えている。 2 では 1 と 3 に間違 えているが, 特に 1 と間違えており, その他 3 と 4,5 と 6 と, 形のよく似たもの同士を間違えて いた。

<実験 $2>$ Fig. 5 に試料の大きさと誤答数の関 係を示した。口による試料形態の識別ではニン ジン大型の 誤答数は $2.1 \pm 0.3$, ニンジン中型は

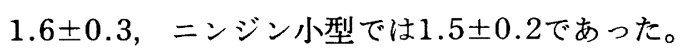
同様に口によるトウフ大型 の識別誤答数 は $1.7 \pm$ 0.3 ，トウフ中型は $1.6 \pm 0.4$, トウフ小型は $1.7 \pm$ 0.2であった。ニンジン，トウフ共に口による形態 識別では大きさによる誤答数に 統計的に有意な差

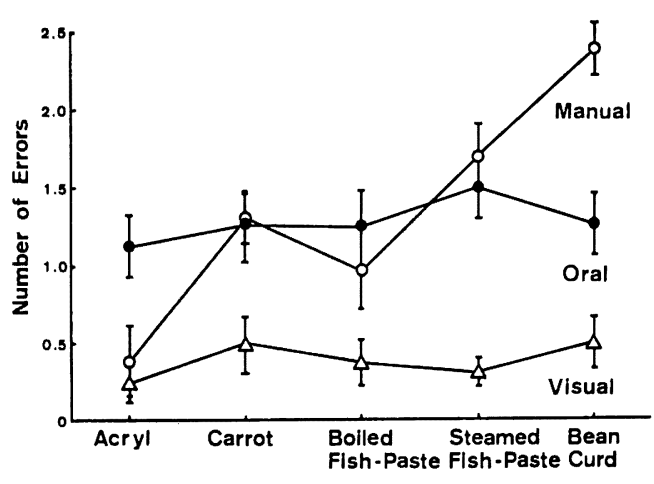

Fig. 4 Difference of discrimination sensitivity among visual, oral and manual test.

はみられなかった。

手による識別ではニンジン大型は $0.9 \pm 0.2,=$ ンジン中型は $1.2 \pm 0.3$, ニンジン小型は $1.7 \pm 0.3$ であり，小さくなるほど誤答数が有意に多くなっ た（p<0.05）。同様に手による識別の誤答数では トウフの大型は $1.3 \pm 0.2$, トウフの中型は $1.9 \pm$ 1.3 ，トウフの小型は $2.4 \pm 0.2$ となった。

<実験 $3>3$ 件法では $1 / 3$ の 確率で 正解の可能 性があるので, プロビット法で処理した。縦軸に 正解率 (プロビット值) を示す (Fig. 6) と, 口 および手による形態識別ともに，棈円の長軸と短

Table 2 The number of error judgments.

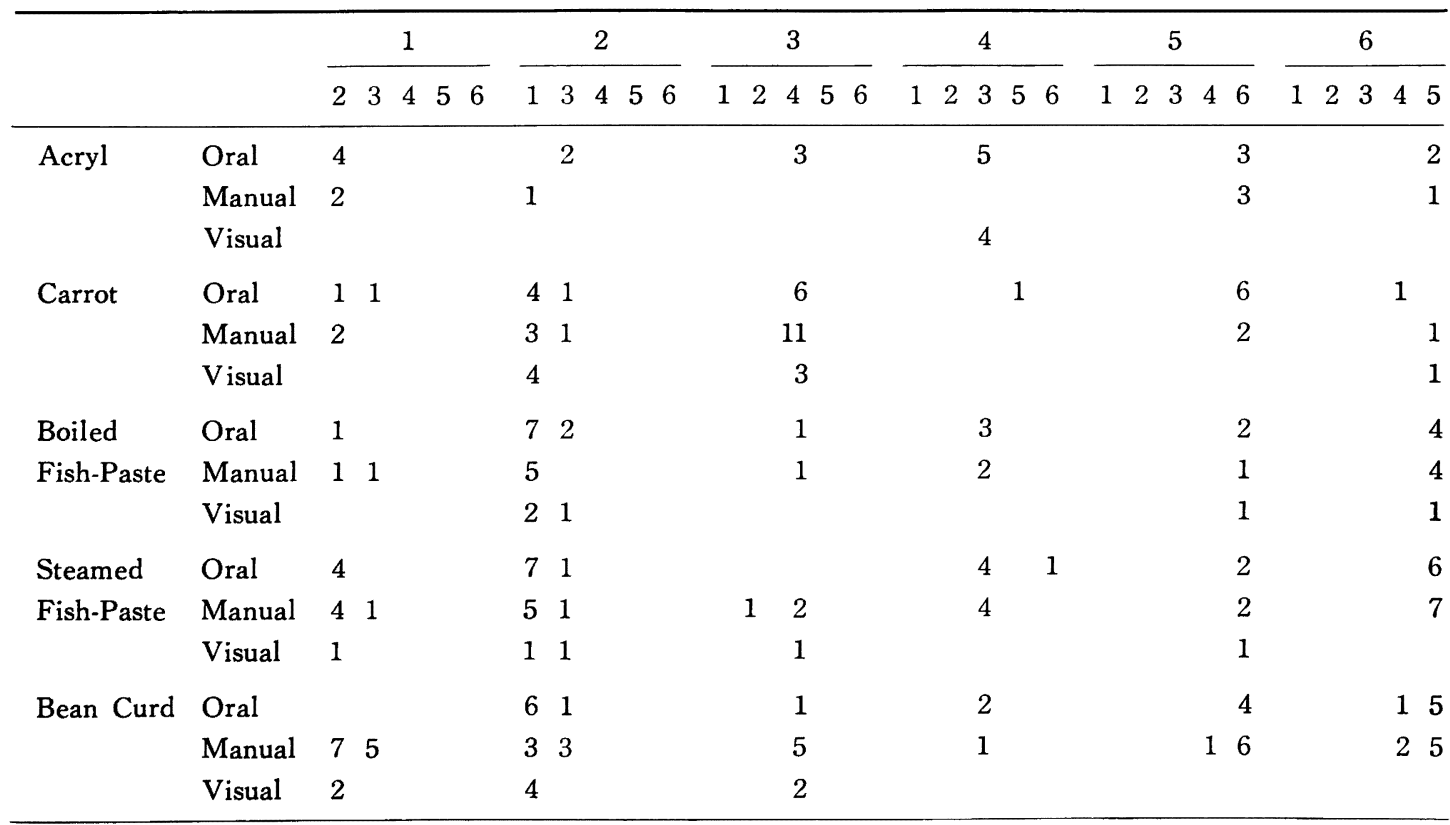



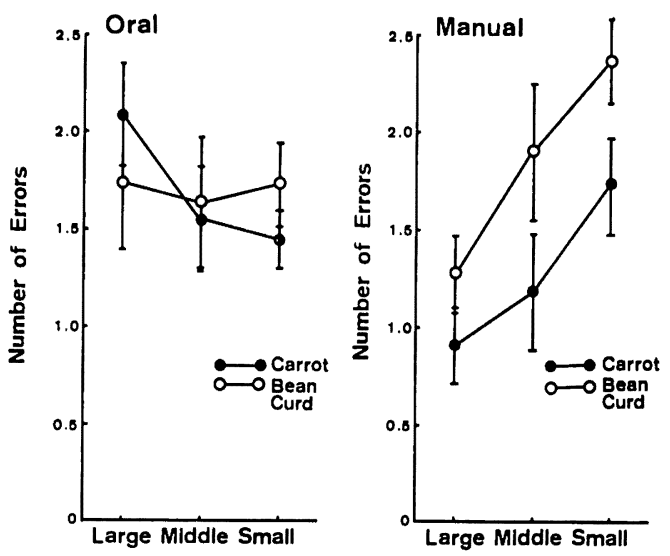

Fig. 5 Difference of discrimination sensitivity. A : Incase of oral. B : In case of manual.

軸の長さが異なると正解率が高く，棈円の長軸と 短軸の長さが接近してくると正解率が 下がった。 $50 \%$ の正解率の点を求めると， 口による棈円の識 別ではアクリル 9.18, ニンジン $8.99, \quad$ トゥフ 8.78 と試料の硬さによる正解率の差は少なかったが, 手による判断ではアクリル 9.66, ニンジン 9.38 , トウフ7.99と，最も軟らか、トウフはアクリル， ニンジンよりも正解率が低かった。

\section{考察}

本実験では従来十分には明らかになっていなか った口腔感覚による食品の形態の弁別・認知の 能 力と食品の物理的性質であるテクスチャーとの関 係について検討し，口腔での食品形態の識別能の 特徴が明かとなった。
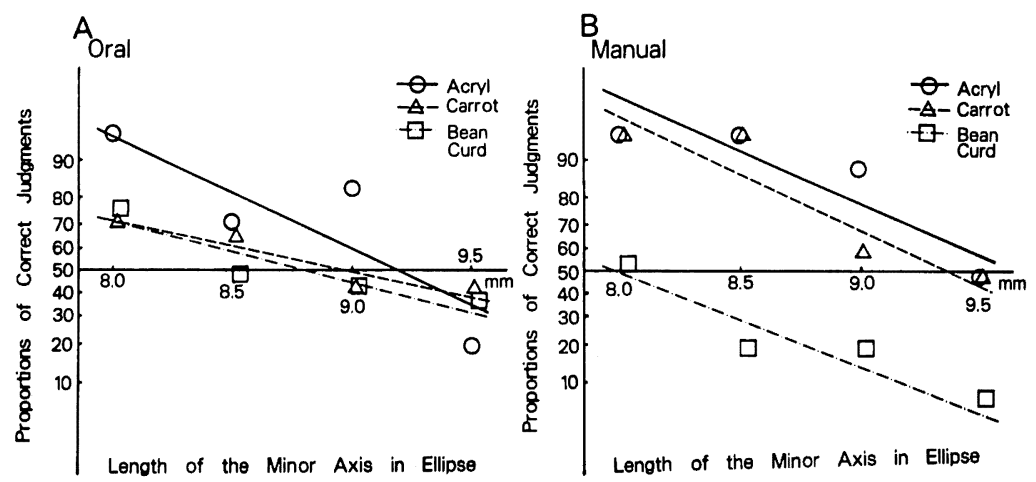

Fig. 6 Proportions of correct judgments (Probit values). A : In case of oral. B : In case of manual.
実験 1 （Fig．4）の手による形態識別と比べて ロによる形態識別では，最も硬いアクリルでは手 に比べ誤答数が多く，ニンジン，カマボコ，ハン ペンでは両者にほとんど差はみられなかったが, 硬度の一番低いトウフについては口の感覚による 識別の 誤答数が手により判断された誤答数より少 なかった。実験 3 （Fig. 6）の円と棈円の識別に おいても，手では軟らかい食品より硬い食品のほ うが形態弁別能が良いのに対して，口では硬い食 品と軟らかい食品と同程度の形態弁別能をもって いることが示唆された。このことより軟らかい試 料の形態識別の能力は手よりも口の感覚の方が 優 れていると考えられる。手ではトウフのような軟 らかい試料の識別性が悪かった理由は，軟らかい 物質の識別性が悪いことが考えられるが，さらに 口の中で舌などを使って試料を扱うより，視覚の 補助なく手指の上で試料を扱うことの 困難さにも 起因していると考えられる。また，口腔組織は柔 軟で可動性に富み，比較的軟らかい物質にも対応 した形の変化を起こすことができる。それは物体 の接触面積を大きくし，中枢へ入力できる感覚情 報を多くできるのではないかと推測される。この ように手では軟らかい食品より硬い食品のほうが 形態弁別能が良いのに対して，口では硬い食品と 軟らかい食品と同程度の形態弁別能をもっている ことが示唆された。

Weinberg ら ${ }^{10)}$ は, 同一試料を用い口, 手, 感覚による形態の識別能の実験を行い，視覚が最 も識別能がよく，続いて手，口の順になることを 
報告した。しかし本実験では試料の硬度を変える と, 手と口の形態識別能力の順位が変わり, 試料 のテクスチャーにより手と口の 形態識別の能力が 異なることを示唆した。

Weber ${ }^{14)}$ は皮膚の空間 2 点弁別䦭は体の他の 部位に比べてきわめて低く, 舌尖 $1.1 \mathrm{~mm}$, 指頭 2.2 $\mathrm{mm}$ と指頭より舌尖のほうがよいとしている。河 村 ${ }^{15}$ によれば皮膚の空間 2 点弁別閾は舌尖綎 0.80 $\mathrm{mm}$, 横 $0.68 \mathrm{~mm}$, 舌表面縦 $4.87 \mathrm{~mm}$, 横 $3.24 \mathrm{~mm}$, 口蓋縌 $2.40 \mathrm{~mm}$, 横 $2.24 \mathrm{~mm}$, 指尖縦 $1.80 \mathrm{~mm}$, 横 $0.20 \mathrm{~mm}$ と, 方向によって感覚闇が異なるとして いる。試料の形態識別は空間 2 点弁別とは異なる 識別能力を測定していると考えられるが， 2 点識 別能力と形態識別能力は密接な 関連があると考え られる。

試料の形態識別の判断には舌ももちろんである が歯牙感覚や口蓋粘膜感覚も関与していると考え られる。舌, 口蓋の場合機械受容器を介して, 歯 牙の場合は歯根膜を介して食品形態の情報が 伝達 されると推測される。舌, 口蓋にはマイスナー小 体，メルケル触覚盤などパチニー小体を除くすべ ての受容器があり，歯根膜にはクラウゼ小体，八 フィー二小体, 自由神経終末が存在している ${ }^{16)}$ 。 堀尾, 河村 ${ }^{11,12)}$, 河村, 堀尾 ${ }^{17)}$, Horio \& Ka- wamura $^{18)}$ は, 食品のテクスチャーによって咀嚼 運動が異なることを報告している。本研究で得ら れた食品テクスチャーの口腔の優れた 形態識別能 は，食品テクスチャーが咀嚼運動へ影響を及ぼす 機序に重要な役割を果たしているものと推測され る。

実験 2 （Fig. 5）より，口による試料形態の識 別ではニンジン，トウフともに大・中・小の大き さによる誤答数の有意な相違はみられなかった が，手の感覚については大きいものより小さいも のの形態識別の間違いが有意に多く，手では小さ いものの形態識別がロに比べ悪いことを示唆して いる。すなわち，手に比べて口では比較的小さい ものの形態識別が良いことが示唆された。

\footnotetext{
謝辞：本実験データの統計的処理については, プロビ ット法は味の素中央研究所の山口静子先生に, 分散分析 法では大阪大学人間科学部投石保広先生のご指導を睗っ た。ここに心より感謝申し上げる。また本実験遂行にあ たり協力いただいた子園大学の佐古美奈子助手ならび に研究生松岡美子さん，松本弘子さんに感謝申し上げ
} る。

本研究の要旨は平成 2 年10月21日東京歯科大学におい て開催された第32回歯科基礎医学会において発表した。

抄録 : 健康な男女大学生を対象に口腔感覚による食品形態の識別能と 食品のテクスチャーの関係を調 ベ た。また手，視覚による形態識別能と口腔感覚による識別能とを比較し検討した。

1. 口による試料形態の識別では硬さの違いよって誤答数にあまり違いはみられなかったが，手による形 態の識別では硬度の高いアクリルは硬度の低いトウフに比べ誤答数が少なく，形態識別能がよくなった。手 では軟らかい食品より硬い食品のほうが形態弁別能が良いのに対して，口では硬い食品と軟らない食品と同 程度の形態弁別能をもっていることが示唆された。

2. 口の感覚による試料の識別能は大きいもの $(30 \mathrm{~mm} \times 12 \mathrm{~mm})$ と小さいもの $(10 \mathrm{~mm} \times 4 \mathrm{~mm})$ とでほと んど変わりはなかった。しかし，手の感覚による識別では小さいものより大きいものの方が優れていた。手 に比へててでは比較的小さいものの形態識別が良いことが示唆された。

\section{文献}

1) Kiesow, F.: Zur Psychophysiologie der Mundhole. Z. Psychol. 33 : 424-443, 1903.

2）岡島速雄, 出井義教, 三宅直春 : 口腔内感覚に ついて. 歯科学報. $52: 29-34,1952$.

3）三宅直晴 : 口腔内感覚点の分布について．第 1 報上顎粘膜の感覚について。歯科学報. 51 : 181-186, 1951.
4）三宅直晴：口腔内感覚点の分布について. 第 2 報下穎粘膜の感覚について。歯科学報. 52 : 29-34, 1952.

5) Kawamura, Y. and Watanabe, M.: Studies on oral sensory thresholds. I . The discrimination of small differences in thickness of steel wires in presons with natural and artificial dentitions. Med. J. Oska Univ. 10 : 291$301,1960$. 
6）渡辺正美：口腔感覚に関する歯科学的研究. I. 天然歯と義歯の物質弁別能の相違について．補 緅誌 3 : 225-229，1959.

7）渡辺正美 : 口腔感覚に関する歯科学的研究. II. 男女，年路および咬合状態による物質弁別能の 相違について. 阪大歯学誌 $7: 17-20,1962$.

8）渡辺正美 : 口腔感覚に関する歯科学的研究. III. 各種義歯で啮んだ場合の物質弁別能の相違につ いて. 阪大歯学誌 $7: 21-28,1962$.

9）渡辺正美：口腔感覚に関する歯科学的研究. IV. 口腔軟組織の物質弁別能について. 阪大雪学誌 7 : 109-114, 1962.

10) Weinberg, B., Lyons, S. M. J. and Liss, G. M.: Studies of oral, manual, and visual form identification in children and adults. In : Bosma, J. F. (ed.) Second Symposium on Oral Sensation and Perception. Charles C Thomas Publisher. pp. 340-349, 1970.

11）堀尾 強, 河村洋二郎 : 咀嚼運動に及ぼす食品 テクスチャーの影響. 歯科基礎誌 30 : 481488, 1988a.

12）堀尾 強, 河村洋二郎 : 姿勢の相違による咀緭
動作の変化とその機序に関する研究. 歯科基礎 誌 30 : 524-532, $1988 \mathrm{~b}$.

13) Shelton, Jr. R. L., Arndt, Jr. W. B. and Hetherington, J. J.: Testing oral stereognosis. In : Bosma, J. F. (ed.) Symposium on Oral Sensation and Perception. Chales C Thomas Publisher. pp. 221-243, 1967.

14）W eber (1846) 感覚+知覚ハンドブック，和 田陽平，大山正，今井省吾(編) 誠信書房から の引用 pp.815, 1969.

15）河村洋二郎：新編口腔生理学 下巻,永末書店, pp.251-252, 1957.

16）坂田三弥, 鈴木 隆 : 口腔感覚 In : 基礎歯科 生理学 坂田三弥, 中村嘉男 (編) 医歯薬出版 pp.330-350, 1987.

17）河村洋二郎，䦙尾 強：咀嚼機能強化食品によ る咀嚼訓練の効果. 歯科基礎誌 $31: 281-290$, 1989.

18) Horio, T. and Kawamura, Y.: Effect of texture of food on chewing patterns in the human subject. J. Oral Rehabili., 16 : 177183, 1989. 